\title{
Corynebacterium in Ancient Egypt
}

\author{
ALBERT ZINK, U REISCHL, H WOLF, A G NERLICH, \\ and ROBERT MILLER*
}

Recent molecular analysis of pathogenic bacterial DNA recovered from a dental abscess in the mummified head of a woman more than sixty years old, buried in K95 in Dra Abu el Naga in the necropolis of western Thebes, has identified Corynebacteria as one of the pathogens present in the New Kingdom, c. 1550-1080 BC, either in the original inhabitant of the tomb or in a later, intrusive New Kingdom burial following tomb robbing. 'The amplification of Corynebacterial DNA, although it cannot be specifically identified as Corynebacterium diphtheriae, may perhaps be complemented by magical texts dating from between about 1850 and $1550 \mathrm{BC}$, which describe the treatment for a childhood disease, here tentatively (and perhaps tenuously) identified with diphtheria. Such research underlines the value of seeking to combine textual, clinical, epidemiological and molecular biological evidence to reconstruct medical history.

Only the head of this female mummy was found. The treatment of this part of the body is typical of New Kingdom mummification techniques, but we had no internal organs and no evidence for other diseases from this individual. The tomb itself originated in the Middle Kingdom, but the chamber from which the sample came was used in the New Kingdom, and only artefacts from this period were found in it. There was no evidence of later burials. We also found the remains of about 40 individuals, mostly incomplete and partially skeletonized, probably as a result of disturbance by contemporary tomb robbers. Looting would explain the absence of Canopic jars in this chamber.

\footnotetext{
* Albert Zink, PhD, and A G Nerlich, MD, PhD, Pathologisches Institut der Ludwig-MaximiliansUniversität, Munich, Thalkirchner Str. 36, 80337 Munich, Germany.

$\mathrm{U}$ Reischl, $\mathrm{PhD}$, and $\mathrm{H}$ Wolf, $\mathrm{PhD}$, Institut für Medizinische Mikrobiologie und Hygiene der Universität Regensburg, Franz-Josef-Strauss Allee 11, 93053 Regensburg, Germany.

Robert Miller, $\mathrm{PhD}$, The Bioanthropology

Foundation Paleoepidemiology Project, 413 6th St, Marietta, Ohio 45750, USA.
}

The authors are grateful to Prof. Dr Daniel Polz and Prof. Dr Rainer Stadelmann (German Institute of Archaeology, Cairo), who provided us with their invaluable help.

\footnotetext{
${ }^{1}$ Albert Zink, U Reischl, H Wolf, and A G Nerlich, 'Molecular analysis of DNA in Egyptian mummy material for the identification of pathogenic bacteria', paper contributed to the Twenty-Sixth Annual Meeting of the Paleopathology Association, Columbus, Ohio, 27 April 1999.
} 


\section{Materials and Methods}

In the field, sterile tissue samples were removed from different tissues, such as bone, teeth, mummified and desiccated inner organs and skin, while avoiding modern contamination. ${ }^{2}$ In the laboratory these samples were subjected to extraction and purification on the DNA using modification of a previous protocol. ${ }^{3}$ Soft tissue samples were processed with QIAmp Tissue Kit (Qiagen, Hilden, Germany) and the bone samples were treated with phenol/chloroform in a Mini BeadBeater device.

The resulting DNA preparation has been amplified by PCR using different sets of well-established in-house consensus primer pairs recognizing conserved regions of the eubacterial 16S rRNA gene, but flanking hypervariable, species-specific regions. The resulting amplification products were analysed by direct cycle sequencing of both strands of the amplicons using an automated DNA sequencer. When several different bacteria were present in one sample, the amplification products were first cloned into TA Cloning Vector and then the isolated clones analysed. Computer-assisted comparison of the determined sequences with all GenBank entries and an in-house eubacterial 16S rDNA databank yielded homology scores leading to a reliable list of candidate bacteria. Particular care was taken to prevent contamination, and multiple controls were run in parallel to the analyses.

As of May 1999, bacterial DNA had been recovered and sequenced from approximately 40 individuals of the sample population of 450 recovered from field work in the New Kingdom necropolis of western Thebes. One sample, from an abscess in a tooth of the woman older than sixty years yielded Corynebacterium spp. DNA (Table 1).

Although this could not be specifically identified as Corynebacterium diphtheriae, diphtheria was endemic in Egypt until recently, and diphtheric paralysis following inoculation with desert sores was observed to be common among British troops stationed in Egypt in $1942 .{ }^{4}$ There could, perhaps, even be late classical period evidence for diphtheria in Egypt if the "Egyptian sores" noted in an early second-century AD eastern Anatolian source were from cutaneous

\footnotetext{
${ }^{2}$ Andreas G Nerlich, C J Haas, A Zink, U Szeimies, and H G Hagedorn, 'Molecular evidence for tuberculosis in an ancient Egyptian mummy', Lancet, 1997, 350: 1404; Albert Zink, C J Haas, E Molnar, U Szeimies, U Reischl, A Màrcsik, Y Ardagna, $O$ Dutour, G Palf, and A G Nerlich, 'Identification of Mycobacterium tuberculosis in different stages of tuberculosis in ancient bone samples from Hungary',

Paleopathology Association papers and posters
}

on paleopathology presented at the thirteenth biennial European members meeting, 18-22 Sept. 2000: 33.

${ }^{3}$ W L Solo, A C Aufderheide, J Buikstra, and $\mathrm{T} A$ Holcomb, 'Identification of Mycobacterium tuberculosis DNA in a preColumbian mummy', Proc. Natn. Acad. Sci., USA, 1994, 91: 1091-4.

${ }^{4} \mathrm{H}$ C M Walton, 'Extrafaucial diphtheria', Lancet, 1970, i: 1395. 
Table 1

Cloned sequence of Corynebacterium DNA from the dental abscess in the mummified head of a more than sixty-year-old woman buried in the New Kingdom necropolis at Dra Abu el Naga, western Thebes, Egypt, c. 1550-1080 BC

\author{
Contig 1 \\ Contig length: \\ 331 bases \\ Average length/sequence: \\ 331 bases \\ Total sequence length: \\ 662 bases \\ Top strand: \\ 2 sequences $>$ \\ Bottom strand: \\ 0 sequences \\ Total: \\ 2 sequences

\section{GGTTCCCCTACGGCTACCTTGTTACGACTTCACCCCAGTCATCGGCCACACCG TGGTAAGCGTCCTCCTTGCGGTTAGA CTACCTACTTCTGGTGCAACAAATTCCCATGGTGTGACGGGCGGTGTGTACAA GGCCCGGGAACGTATTCACCGCGGCA TTCTGATCCGCGATTACTAGCGATTCCGACTTCATGGAGTCGAGTTGCAGACT CCAATCCGGACTACGATCGGCTTTTT GAGATTAGCATCCTATCGCTAGGTAGCAACCCTTTGTACCGACCATTGTAGCA CGTGTGTAGCCCTGGTCGTAAGGGCC ATGATGACTTGACGT}

diphtheria, ${ }^{5}$ and not skin lesions resulting from leishmaniasis, anthrax, psoriatic arthritis or streptococcal impetigo. Diphtheria remained endemic in East Africa in the twentieth century $\mathrm{AD}$, with approximately 80 per cent of a rural population showing antibody titres largely derived from past natural infection in one study in Kenya. ${ }^{6}$

The discovery of Corynebacterial DNA in an ancient Egyptian does not permit identification of the species. The genus Corynebacterium includes many species, some of which normally occupy the mouth and are not pathogenic. There may also, perhaps, be somewhat tenuous evidence of diphtheria in two Pharaonic

\footnotetext{
${ }^{5} \mathrm{P}$ C English, 'Diphtheria and theories of infectious disease: centennial appreciation of the critical role of diphtheria in the history of medicine', Pediatrics, 1985, 76: 1-9, cites Aretaeus the Cappadocian (81-138 AD), Causes and symptoms of acute diseases, Book 1, ch. 9, for a description of "Egyptian" or "Syrian" ulcers or eschars on the pharynx. Aretaeus warned that "if it spreads to the thorax by the windpipe, it occasions death by suffocation within the space of a day" and observed that "children, until puberty, especially suffer", according to English's quotes from the translation by F Adams, Extant works of Aretaeus the Cappadocian, London,
}

printed for the Sydenham Society, 1856, pp. 253-5. English comments that "The Egyptian ulcer with its hoarseness, difficulty in swallowing, eschar and suffocation certainly sounds like diphtheria" (op. cit., p. 3). This reference is cited with reservation as "diseases resembling diphtheria" by Ann G Carmichael, 'Diphtheria', in K F Kiple (ed.), The Cambridge world history of human disease, Cambridge and New York, Cambridge University Press, 1993, pp. 680-3.

${ }^{6}$ Jorgen A L Kurtzhals, K Kjeldsen, A S Hey, E A Okong'o-Odera, and I Heron, 'Immunity to tetanus and diphtheria in rural Africa', Am. J. Trop. Med. Hyg., 1997, 56: 576-9. 


\section{Albert Zink, U Reischl, $H$ Wolf, A $G$ Nerlich and Robert Miller}

magical texts, referring to $J_{\text {二 }} 11 b^{\prime \prime}$, a condition affecting mothers and infants identified as a disease of childhood (Kinderkrankheit) in the authoritative German Grundriss. ${ }^{7}$

In the collection of ancient Egyptian paediatric magic and prescriptions preserved in a copy from $c$. $1550 \mathrm{BC}, b^{\prime \prime}$ is noted as a condition, possibly affecting the throat, to be treated by herbal remedies, but without any indication of its nature. ${ }^{8}$ However, clinical symptoms of $b^{\prime \prime}$-disease noted in a Middle Kingdom (after 1854 BC) paediatric magical text from a papyrus found behind the Ramesseum at Thebes included possible cardiac complications resulting in cyanosis (blue lips) and temporary paralysis usually affecting young children. ${ }^{9}$ The Ramesseum text also lists $b$ "-disease among throat diseases. These symptoms suggest a diagnosis of diphtheria, ${ }^{10}$ which would be consistent with the presence of Corynebacterium in the local population during Pharaonic times, although further palaeoepidemiological research in East African Corynebacterial DNA would be needed to confirm identification with diphtheria, which must remain only a hypothesis at present. The occurrence of $b$ "'-disease among children also corresponds to the typical age of diphtheria cases in north-eastern Africa recently. In Sudan between 1979 and 1986 the majority of reported cases (55.2 per cent) occurred in children from 0 to 4 years old, with only 1.2 per cent of reported cases over 15 years old. ${ }^{11}$

Although these two texts contain the only two Pharaonic period references to $b^{\prime}$ '-disease published at present, ${ }^{12}$ the characteristics of this condition seem clear, but its absence from major medical texts such as the Ebers and Hearst papyri should be noted. It affected children and their mothers, and the ancient Egyptians believed that it was transmitted to the child in the mother's milk during nursing. However, it was possible to cure $b^{\prime \prime}$-disease, as Isis had cured her infant, Horus:

So said Isis the goddess: "I had beaten my locks, I had disordered my hair after I found my son Horus with a weary $i b$, his lips livid, his legs weak when he had sucked in the $b$ " that was in my bosom, the bitterness of my breast ..." "Come to the humans with me, mother", said Horus, "and you, my aunt Nephthys, to the places where the nurses are and the maids of Nut, that they may tell us what they have done for their children. Then we can do something similar for the children of [long gap to fill in with

\footnotetext{
${ }^{7} \mathrm{H}$ von Dienes and $\mathrm{W}$ Westendorf, Wörterbuch der medizinischen Texte, Grundriss der Medizin der alten Ägypter, vol. VII,1, Berlin, Akademie-Verlag, 1961, pp. 244-5.

${ }^{8}$ A Erman, Zaubersprüche für Mutter und Kind: aus dem Papyrus 3027 des Berliner Museums, Berlin, Abhandlungen der Königlichen Preussischen Akademie der Wissenschaften, 1901, pp. 28-9.

${ }^{3} \mathrm{~J}$ W B Barns (ed.), Five Ramesseum papyri, Oxford, The Griffith Institute/Oxford University Press, 1956, pp. 22-3. Some of the furnishings in the tomb where this text was found suggest that the text may, perhaps, have belonged to a magician/medical practitioner (John F Nunn,
}

Ancient Egyptian medicine, London, British Museum Press, 1996, pp. 39-40).

${ }^{10}$ A B Christie and Tran Tinh Hien,

'Diphtheria', in D J Weatherall, J G G

Ledingham and D A Warrell (eds), Oxford textbook of medicine, 3rd ed., Oxford, and New York, Oxford University Press, 1996, vol. 1, pp. 493-7.

"B P Loevinsohn, 'The changing age structure of diphtheria patients: evidence for the effectiveness of EPI in the Sudan', Bull. World Health Org., 1990, 68: 353-7.

${ }^{12}$ Von Dienes and Westendorf, op. cit. note 7 above. 


\section{Corynebacterium in Ancient Egypt}

the name of patient's parents]." Isis the goddess, with Nephthys: "It is on behalf of my son Horus that I have come. His $i b$ is very weary, his legs are weak [from] the $b$ " that is in my bosom, the bitterness that is in my breast. Its hostile effects will be closed with seven flax stalks, twisted and plaited with a spindle by a woman who has just given birth. A nestling swallow will be brought and its eyes painted with ... and black eye-paint [for] this child and its mother. And its b' -demon is [transferred to] the swallow!" This spell is to be said over seven flax stalks twisted and plaited with a spindle by someone who has just given birth. Seven knots are to be made in it and it is to be applied to the child's throat. A swallow will be brought to its mouth. ${ }^{13}$

By bringing the patient into a magical narrative connecting the child's experience with that of the infant god Horus, who had successfully recovered from $b^{\prime \prime}$ disease thanks to the intervention of his mother, both patient and parents could be comforted by the possibility of a hopeful outcome, which often did occur. Even before the development of antitoxin against diphtheria in the $1890 \mathrm{~s}$, it is worth noting that approximately 7 out of 10 children recovered without therapy. ${ }^{14}$

The isolation, amplification and identification of pathogenic and possibly pathogenic bacteria from Pharaonic Egyptians, taken in conjunction with the identification of pathogen antigens in ancient populations ${ }^{15}$ marks the crossing of a significant threshold in the study of ancient medical history, making it possible to work directly from the preserved and even fragmentary remains of

\footnotetext{
${ }^{13}$ Papyrus Ramesseum III, B, 23-24, in Barns (ed.), op. cit. note 9 above, pp. 22-3; trans. J F Borghouts, Ancient Egyptian medical texts, No. 69, Leiden, Brill, 1978, pp. 43-4, with minor alterations for non-Egyptological readers. For a magical spell written down, folded and tied around the neck of the patient, see S Sauneron, 'Le rhume d'Anynakhte', Kêmi, 1970, 20: 7-18, and for the involvement of the patient's family and literate neighbours in providing primary health care, see R Miller, 'Palaeoepidemiology, literacy, and medical tradition among necropolis workmen in New Kingdom Egypt', Med. Hist., 1991, 35: 1-24, esp. p. 17.

${ }^{14}$ In New York City from 1891 to 1894 there were 7,126 deaths in 25,151 cases of diphtheria, a 28.3 per cent case fatality rate. Following the introduction of antitoxic serum, annual case fatality rates fell from 16.4 per cent in 1895 to 10.9 per cent in 1898 (H M Biggs, 'The serum treatment and its results', Med. News, 1899, 75 : 97-105). In 1890, the population of New York City, which was limited to Manhattan, was 1,515,000 (Edwin G Burrows and Mike Wallace, Gotham: a history of New York City to 1898, New York, Oxford University Press, 1999, p. 1223), so the prevalence of diphtheria was approximately 1 in 60 over the four years recorded. Although diphtherial Corynebacterium DNA would be expected to occur somewhat less frequently in
}

remains of skeletons from 1890 s Manhattan than in the 1 out of 40 Pharaonic individuals in western Thebes who tested positive for the presence of generic Corynebacterium DNA, the relative prevalence is comparable, and pathogens would be expected to occur above background levels of non-pathogenic species in individuals affected by the disease at the time of death.

${ }^{15}$ Andre M Deelder, R Miller, N De Jonge, and $\mathrm{F}$ W Krijger, 'Detection of schistosome antigen in mummies', Lancet, 1990, 335: 724-5; Robert Miller, G J Armelagos, S Ikram, N De Jonge, F W Krijge, and A M Deelder, 'Palaeoepidemiology of schistosoma infection in mummies', Br. med. J., 1992, 304: 555-6; Robert Miller, N De Jonge, F W Krijge and A M Deelder, 'Predynastic schistosomiasis', in W V Davies and R Walker (eds), Biological anthropology and the study of ancient Egypt, London, British Museum, 1993, pp. 54-60; Robert Miller, S Ikram, G J Armelagos, R Walker, W B Harer, C J Shiff, D Baggett, M Carrigan, and S M Maret, 'Diagnosis of Plasmodium falciparum infections in mummies using the rapid manual ParaSight-F test', Trans. R. Soc. Trop. Med. Hyg., 1994, 88: 31-2; and Robert Miller, D D Callas, S E Kahn, V Ricchiuti and F S Apple, 'Evidence of myocardial infarction in mummified human tissue', $\mathrm{J}$. $\mathrm{Am}$. med. Ass., 2000, 284: 831-2. 
Albert Zink, U Reischl, $H$ Wolf, $A$ G Nerlich and Robert Miller

individuals from past populations to investigate the history and evolution of disease. As the DNA from isolates of Corynebacterium diphtheriae from modern populations is studied, it is hoped it will be possible to add information about evolution and maintenance of pathogen genome drawn directly from the remains of ancient populations in different areas of the world to complement the analysis of genetic variation among contemporary populations of Corynebacteria. 